SEBASTIAN KOT, Ph.D.

E-mail: sebacat@zim.pcz.czest.pl

Czestochowa University of Technology,

Faculty of Management

Armii Krajowej 19B, 42-200 Czestochowa, Poland
Transportation Economy

Preliminary Communication

Submitted: Nov. 12, 2014

Approved: Oct. 6, 2015

\title{
COST STRUCTURE IN RELATION TO THE SIZE OF ROAD TRANSPORT ENTERPRISES
}

\begin{abstract}
The problem of cost management in road transport enterprises is one of the most crucial ones for their efficient functioning. The enterprises functioning on the market are very different so it is important to analyse their costs structure in relation to their size. The author provides a discussion on road transport costs identification and problems related to it. The considerations are based on the background of road transport importance in transport services in Poland and chosen European Union countries. Then, the research methodology consisting of elaborated questionnaire and the research sample are defined with special attention to the company size. The author provides research results on the costs structure in road transport enterprises in southern Poland and presents their components and differences. The author noticed the differences in costs structure in relation to the company size with domination of employment costs in micro and small road transport enterprises and costs of fuel in larger companies that result from better resource management.
\end{abstract}

\section{KEY WORDS}

road transport; costs structure; fuel cost; company size; performance analysis;

\section{INTRODUCTION}

Transport is an inherent element which accompanies every type of economic and public activity and enables them to meet the natural need of people mobility; therefore its functioning and development have a universal character [1,2]. Transport is one of the subsystems of the logistic system. This is the system most considered for optimization within the logistic process. Other subsystems include: order processing, stock, warehousing and packaging. Transport means goods are moved from one point to another with the help of transport vehicles. The transport of goods from factory to factory is part of the distribution function of the supplier as well as part of the procurement function of the receiver $[3,4]$.

Furthermore, transport processes are essential parts of the supply chain. They perform the flow of ma- terials that connects an enterprise with its suppliers and with its customers. The integrated view of transport, production and inventory holding processes is characteristic of the modern logistics and supply chain management (SCM) concept [5, 6, 7].

Road transport is the most often used branch of transport, whose means are vehicles transporting cargoes and people; this branch owes its popularity and rapid development to such features as [8]:

- spatial diversity of roads being characterized by the greatest density and cohesion;

- the most beneficial adaptation of road networks to arranging places of production, trade and consumption;

- adapting means of transport to transport of almost all kinds of cargoes; in addition general cargoes of high unit values are a mainstay of road transport;

- good attributes connected with the time of duration of transport.

In the European Union countries transport performs a key role; the share of road goods transport measured in tonne-kilometres amounts to, $44.9 \%$ of total transport, while rail amounts to $10.8 \%$, inland waterways - $4 \%$ and pipelines - 3\%. Intra-EU maritime transport was the second most important mode with a share of $37.2 \%$ while intra-EU air transport only accounted for $0.1 \%$ of the total in 2012 [9]; taking into consideration the analysis of Polish transport the dominance of road transport is even more visible. Road transport is the basic branch of transport in Poland; it is assumed that approximately almost $12 \%$ of incomes of the state budget is generated through this industry in 2013. It can be evaluated that the participation of road transport in the realization of current supply of goods amounts to $80 \%$ in systems of transport of individual countries. This sector employed about 450 thousand workers directly connected with transport, including drivers, carriers and employees of technical and administration constituting altogether a powerful economic sector in 2013 [10].

Growing importance of Polish road transport on markets of the European Union is based undoubtedly 
on the access to the large fleet of road vehicles, which grows more quickly than Polish GDP. In 2012 the number of companies dealing with road transport grew by more than $127 \%$ i.e. from 1,548 to 3,517 thousand comparing to 2003. In Poland small and medium sized companies of road transport, which have 6 - 9 or 10 - 19 cars, dominate. These companies accounted for as much as $96 \%$ of the total licensed transport companies and more than $65 \%$ of total capacity [11]. In the year 2012, two percent of all shipping companies in Poland were large firms holding above 100 lorries.

The issue of transport costs management incurred in the context of logistic processes is regarded as one of the toughest and most complex problems faced by the logistic sector [12].

The starting point for the activities aimed at rationalizing and reducing the level of transport costs is to understand the complexity of their nature in the various links of logistic systems in supply chains. A skilful grouping of transport costs favours the analysis of "image" of costs and its changes under the impact force of various internal and external factors.

Transport costs consist of many different positions of costs of performing services, fuel, depreciation, administration, etc. $[13,14]$. The sum of costs can be divided into those which depend on the quantity of transported goods and those which do not come under such diversity.

In calculating prices in transport, it is possible to assume that they do not change in the case of normal operating amounts of the carrier and are fixed costs, and all others are variable costs. So, a depreciation of means of transport and salaries of administrative staff will be fixed costs, price of transport including fuel, salaries of employees serving means of transport, equipment maintenance, receipt of goods and its delivery usually constitute variable costs [15].

Apart from transport costs, studies of the effectiveness of transport processes are also significant; these problems are analysed with reference to the chosen transport issues. So, while using quantitative indicators it is possible to study the effectiveness of transport system in view of:

- number of means of transport;

- number of work hours of means of transport;

- number of covered kilometres;

- number of kilometres per one means of transport;

- number of workers employed in transport department;

- number of kilometres per one driver;

- number of breakdowns of means of transport.

Considering the size and structure of the costs incurred by the shipping companies it seems simple. After taking into account the obvious fuel costs, driver salary and road tolls depreciation cost must be added, which is not easy to identify because of the lack of a clear answer to the question of how long the ve- hicle lifecycle will last. The proportion of added insurance costs, repairs, maintenance, tyre replacement and maintenance parts must be taken into account as well. Another important element complicating the calculation of costs in relation to the transport rate is variability in time and space dependent on the acquisition price of fuel.

There is lack of detailed elaborations in road transport costs in companies although many authors deal with various transport cost scopes as internal and external costs of transport with relation to total costs of private transport and public transport [16, 17]; cost of road transportation within intermodal system [18, 19] idea of or generalized transport costs of goods in intermodal transport [19]. Kulović, as one of the few, solved the problem of road transport costs modelling in relation to truck fleet operational parameters [20].

Considering the above mentioned problems of costs identification and knowledge niche on road transport costs in enterprises, the aim of this paper is to present and analyse costs structure in road transport enterprises and discuss the problem related with different costs structure in relation to company size. The thesis of this paper is: various costs structure in road transport enterprises is one of the main reasons of the transport companies' problems in the present turbulent business environment.

\section{RESEARCH RESULTS AND PRESENTATION OF METHODS}

In order to accomplish the purpose of this paper a research questionnaire was used, which showed the operating cost generated in transport companies. The research was conducted via e-mail in the first quarter of 2014. The questionnaire was sent to randomly selected road transport companies in the private sector in the Silesian region in Poland. The analysis encompassed micro, small, medium and large companies (recognized on the basis of the number of persons employed) carrying out the paid and economic transport using delivery trucks with a laden weight of above 3.5 tonnes. These companies figure in the Central Statistical Office register and specialize in:

- transport of goods carried by using vehicles of road transport adapted for transport of goods of different kinds: livestock, frozen or cooled goods, bulk goods, heavy goods, long timbers, waste, recycled materials - excluding their collection and removal; - lease of lorries with drivers.

For the examined population of road transport enterprises in the Silesian region in Poland, the sample of $\mathrm{N}=51$ enterprises was formed. The sample structure is in accordance with the population structure. The sample insured the maximal margins of error $+/-10 \%$ at the confidence level of $95 \%$. 
The obtained replies were combined with the size of the examined companies, which allowed for estimation of average costs of the activity in every category of companies. The questions included in the questionnaire were drawn up with the help of available literature dealing with costs generated in transport $[8,12]$.

The greatest participation of companies depending on their size were small and medium ones (43 companies in total, i.e. $84 \%$ of all the studied ones). Large firms employing more than 250 workers and micro companies participated in the research most rarely. On this basis it is possible to make the statement that analysis of the given replies concerned in the vast majority of small and medium entities of the transport industry. Considering the structure of the sample and the whole population of goods road transport companies in Poland, there is a significant difference because in the whole population, micro companies are the most common and amount to $97.44 \%$ of all goods road transport enterprises. However, it is a very unclear structure because in this situation micro companies are mainly truck drivers as the self-employed enterprises working for small and medium and large companies that is very common practice of employment cost decrease. So, the structure of the sample is supposed to be much closer to the real structure of the whole population than presented as the effect of costs accounting "play" with employment costs (Table 1).

The scope of transport performed by shipping companies has a significant influence on generated costs and profits from their activity. The question about the scope of transport was regarded important from the point of view of differences between international and domestic transport. International transport was regarded as the subject of consideration in the situation when the company vehicle crosses at least one state border during the transportation of goods. Services of international transport are connected with paying extra charges e.g. customs duties outside the European Union. Even though these payments were limited to the minimum, it is still possible to notice their influence on the created costs and the organization of transport, starting from accepting orders throughout planning routes and taking time zones into account in remote places of supplies or receipts. Among researched com- panies almost $70 \%$ carry out their activity on an international scale. One of every five examined companies limit their transports only to the country.

Next, companies were asked about the number of cars with a laden weight of above 3.5 tonnes in years 2010, 2011 and 2012 according to European standards of emission (Figure 1).

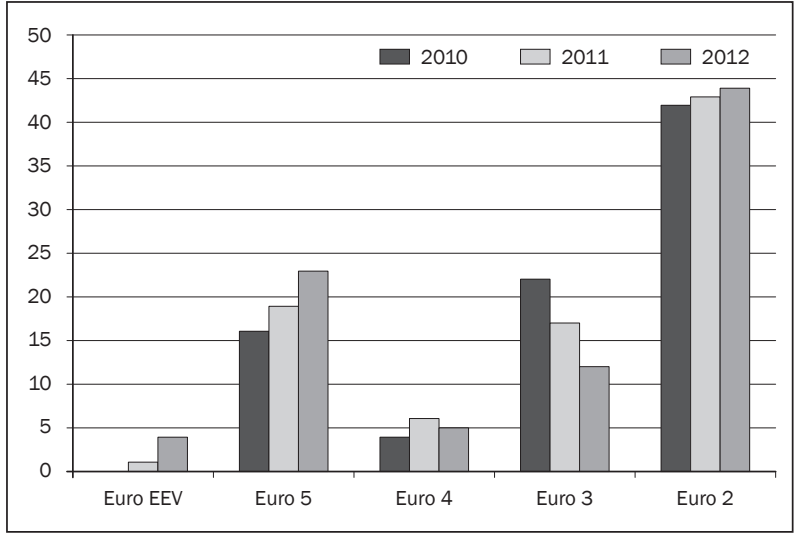

Figure 1 - The structure of owned vehicles with laden weight of above 3.5 tonnes [percentage] Source: Author's elaboration

Lorries intended for the transportation of goods allow companies for the transport of greater quantities of goods. On the one hand, it is a factor which creates costs and profits, since it requires additional qualifications. On the other hand, companies which exploit in their activity vehicles of this type must take into consideration additional legislative and road regulations. Documents, which one should scrupulously respect, are directives of the European Union, which put emphasis on:

- protection of natural environment, hence the European standards of emission and focusing on using more eco-friendly means of transport;

- implementing innovative solutions, e.g. implementation of more aerodynamic cars, which can significantly increase effectiveness of the level of fuel consumption, particularly on long routes;

- moving only via roads intended for the given capacity;

- time of driving vehicles.

Table 1 - The number of studied companies according to general number of employed workers and the structure of population of goods road transport companies in Poland

\begin{tabular}{||l|c|c|c|c||}
\hline \hline \multirow{2}{*}{ The number of researched companies } & \multicolumn{2}{|c|}{$\mathrm{N}=51$} & \multicolumn{2}{c||}{ Whole population in Poland } \\
\cline { 2 - 5 } & $\mathrm{No}$ & $\%$ & No. & 97.44 \\
\hline \hline Micro companies employing up to 10 workers & 6 & 11.76 & 127,448 & 2.31 \\
\hline Small companies employing from 10 to 49 workers & 20 & 39.22 & 3,009 & 0.23 \\
\hline Medium companies employing from 50 to 249 workers & 23 & 45.10 & 307 & 0.02 \\
\hline Large companies employing more than 249 workers & 2 & 3.92 & 31 & 9 \\
\hline
\end{tabular}

Source: Author's elaboration based on the research and [21] 
Only in case of lorries is it possible to include expenses concerning the purchase of the lorry in tax deductible expenses, which in turn lowers the income tax. It is advantageous particularly for these companies, which want to account expenses quickly and whose profits are relatively high.

In transport activity costs of salaries of employees - also of drivers - affect the level of generated operating costs as well. Table 2 presents the average number of drivers employed in the given years and in companies according to their size.

Table 2 - Average number of employed drivers in years 2010-2012

\begin{tabular}{||l|c|c|c||}
\hline Year & 2010 & 2011 & 2012 \\
\hline \hline Micro companies & 5 & 4 & 5 \\
\hline Small companies & 23 & 26 & 28 \\
\hline Medium companies & 73 & 77 & 83 \\
\hline Large companies & 96 & 97 & 102 \\
\hline
\end{tabular}

Source: Author's elaboration

The detailed aim of the research was the analysis of transport activities carried out by the examined companies quantitatively in the years 2009-2012 and more precisely describes the selected cost and organizational aspects of this activity. The companies were asked about the total number of kilometres covered; Table 3 presents the results of the given answers.

Table 3 - Average number of kilometres covered by vehicles of examined entities

\begin{tabular}{||l|c|c|c||}
\hline Year & 2010 & 2011 & 2012 \\
\hline \hline $\begin{array}{l}\text { Micro } \\
\text { companies }\end{array}$ & 344,942 & 336,287 & 366,723 \\
\hline $\begin{array}{l}\text { Small } \\
\text { companies }\end{array}$ & $1,529,246$ & $1,596,091$ & $1,787,755$ \\
\hline $\begin{array}{l}\text { Medium } \\
\text { companies }\end{array}$ & $7,316,188$ & $8,441,198$ & $8,827,761$ \\
\hline $\begin{array}{l}\text { Large } \\
\text { companies }\end{array}$ & $12,793,220$ & $12,812,883$ & $13,244,925$ \\
\hline
\end{tabular}

Source: Author's elaboration

On the basis of data presented in Table 3 it is possible to state that the examined companies covered the greatest number of kilometres in 2012; however, this growth was a little bit smaller than in 2011 in comparison to 2010.

\section{RESEARCH RESULTS DISCUSSION}

The cost of fuel consumption is connected with the number of covered kilometres. It depends on the speed, with which the driver covers their given route $[22,23,24]$ (Table 4).
Large companies bear the greatest costs of fuel consumption; next, within the analysed period, costs of small companies diminished. In addition, the greatest costs of fuel consumption per $100 \mathrm{~km}$ were borne by micro companies in 2011 and by medium and large companies in 2010 , which can be affected by the way of driving the vehicle. Apart from costs associated with the purchase of fuel both earning and economic transport companies also bore other costs connected directly with the transport activity.

Costs associated with the completion of shipments include costs of the salaries and compulsory social insurance and taxes of drivers and the staff dealing with the service of transport orders. These costs are variable related to transportation works and they are not connected with fixed administrative costs. In case of transport companies, from the point of view of the financial burden, the adopted driver employment system is important. Carriers may offer the following forms of employment: contract of employment, contract of mandate or self-employment.

The level of salaries paid in companies according to the number of the employed is presented as follows:

- large companies remunerate the most the staff engaged in transport department;

- micro companies allocate the least for this purpose;

- the level of salary of staff attending transport orders simultaneously falls with the reduction of the number of all the employed in the company.

Next, companies were asked about repairs and maintenance costs (along with costs of consumables e.g. oils, exclusive of costs of technical inspection); conclusions of the obtained replies have been included in Table 4.

Medium and large companies allot the least on repairs of their vehicles, which can be caused by better price conditions resulting from entering into agreements with contracting parties and better conditions of providing credit for the purchasing of new vehicles.

According to recommendations, the greatest average individual costs of repair of the vehicles were borne by micro companies and the least by medium ones. Costs of repairs of the vehicle develop similarly for small, medium and large companies of motor transport.

Vehicles used in business activity are subject to consumption. In connection with that every company is obliged to make capital allowances, which lower the income of the entity. Moreover, it is possible to amortize lorries on a one-off basis, which allows ceding the precise amount from income at once and investing these means somewhere else (in the case of so-called "small" taxpayers).

Next, the overall costs of safeguarding vehicles were considered. Within the activity of road transport two valid insurances were distinguished: liability in- 
S. Kot: Cost Structure in Relation to the Size of Road Transport Enterprises

Table 4 - Average annual costs in examined entities according to company size in thousand euro

\begin{tabular}{|c|c|c|c|}
\hline Year & 2010 & 2011 & 2012 \\
\hline \multicolumn{4}{|c|}{ Average fuel consumption costs } \\
\hline Micro companies & 104.9 & 115.7 & 104.9 \\
\hline Small companies & 490.7 & 482.8 & 476.1 \\
\hline Medium companies & $2,510.6$ & $2,258.7$ & $2,520.7$ \\
\hline Large companies & $4,640.7$ & $4,299.2$ & $4,640.7$ \\
\hline \multicolumn{4}{|c|}{ Costs of salaries } \\
\hline Micro companies & 194.2 & 186.0 & 190.0 \\
\hline Small companies & 397.9 & 410.9 & 427.2 \\
\hline Medium companies & 918.9 & 844.6 & 918.6 \\
\hline Large companies & $1,353.6$ & $1,372.7$ & $1,313.3$ \\
\hline \multicolumn{4}{|c|}{ Costs of repairs and maintenance } \\
\hline Micro companies & 19.7 & 20.0 & 19.6 \\
\hline Small companies & 50.4 & 52.5 & 51.2 \\
\hline Medium companies & 71.7 & 76.4 & 77.1 \\
\hline Large companies & 98.6 & 101.3 & 101.5 \\
\hline \multicolumn{4}{|c|}{ Annual depreciation costs } \\
\hline Micro companies & 9.0 & 5.6 & 2.1 \\
\hline Small companies & 65.4 & 67.9 & 90.9 \\
\hline Medium companies & 185.2 & 211.3 & 263.8 \\
\hline Large companies & 222.8 & 255.1 & 251.3 \\
\hline \multicolumn{4}{|c|}{ Liability insurance of vehicle cost } \\
\hline Micro companies & 1.1 & 1.4 & 1.5 \\
\hline Small companies & 4.4 & 9.6 & 12.7 \\
\hline Medium companies & 39.0 & 42.6 & 65.3 \\
\hline Large companies & 103.2 & 95.0 & 114.1 \\
\hline \multicolumn{4}{|c|}{ Comprehensive motor insurance cost } \\
\hline Micro companies & 1.3 & 1.6 & 1.7 \\
\hline Small companies & 6.8 & 7.4 & 15.8 \\
\hline Medium companies & 42.6 & 70.1 & 57.0 \\
\hline Large companies & 92.5 & 116.4 & 80.7 \\
\hline
\end{tabular}

\begin{tabular}{|c|c|c|c|}
\hline Year & 2010 & 2011 & 2012 \\
\hline \multicolumn{4}{|c|}{ Costs of insurance of transported goods } \\
\hline Micro companies & 0.8 & 1.1 & 1.1 \\
\hline Small companies & 3.0 & 4.1 & 3.3 \\
\hline Medium companies & 4.5 & 5.8 & 5.0 \\
\hline Large companies & 80.0 & 79.9 & 80.0 \\
\hline \multicolumn{4}{|c|}{ Costs of fines connected with delays } \\
\hline Micro companies & 0.1 & 0.2 & 0.4 \\
\hline Small companies & 0.2 & 0.8 & 2.2 \\
\hline Medium companies & 3.6 & 8.3 & 16.4 \\
\hline Large companies & 0.2 & 0.4 & 0.7 \\
\hline \multicolumn{4}{|c|}{ Environmental fees } \\
\hline Micro companies & 0.5 & 0.2 & 0.2 \\
\hline Small companies & 0.3 & 0.2 & 0.2 \\
\hline Medium companies & 0.9 & 0.8 & 0.7 \\
\hline Large companies & 2.1 & 2.1 & 2.2 \\
\hline \multicolumn{4}{|c|}{ Transport vehicle taxes } \\
\hline Micro companies & 1.8 & 2.2 & 1.9 \\
\hline Small companies & 16.9 & 9.1 & 9.2 \\
\hline Medium companies & 26.3 & 30.0 & 30.5 \\
\hline Large companies & 31.4 & 36.5 & 31.8 \\
\hline \multicolumn{4}{|c|}{ Costs of domestic and foreign toll roads } \\
\hline Micro companies & 18.7 & 20.1 & 20.6 \\
\hline Small companies & 39.0 & 39.7 & 40.5 \\
\hline Medium companies & 42.4 & 43.4 & 43.5 \\
\hline Large companies & 28.7 & 30.1 & 30.1 \\
\hline
\end{tabular}

Source: Author's elaboration

surance (third party liability) of carrier in international transport and insurance of cargoes. Enterprises paid also comprehensive motor insurance. Table 4 presents the amounts borne for both kinds of insurances.

According to the size of companies micro companies bore the smallest expenses resulting from the number of owned vehicles, while large entities the least. It is possible to observe a high level of diversification between two kinds of insurances in certain companies, which can be the result of changes in insurance rates, changes of the insurer or the appearance of accidents covered by the insurances. Insurance costs of the carriage of dangerous goods are included in the liability insurance and constitute the extension of its range; penalties for delays in supplies described in Table 4 constitute extra costs.

Average annual costs of penalties resulting from delays in the delivery of goods prove the organizational limited capacities of the company. Delays of supplies

can result not only from the improper transport planning but also from traffic queues, accidents, unexpected vehicle repairs - that is, of factors which are hard to predict. These costs are usually borne by companies carrying gain activity. Examined companies indicated on the average from 17 up to 40 delays within one year, which ended with the need of paying compensation.

Transport companies are obliged to pay environmental fees for an action of different kind and that is its ability to negatively affect the natural environment concerning i.a. gasses or dusts emitted into the air through means of transport. Transport companies pay fees for pollution emissions to the marshal's office twice a year, with jurisdiction over the place of company registration.

Road transport companies pay fees on the basis of the type of vehicle owned and more precisely on the type of engine, standard of emission and date of first 


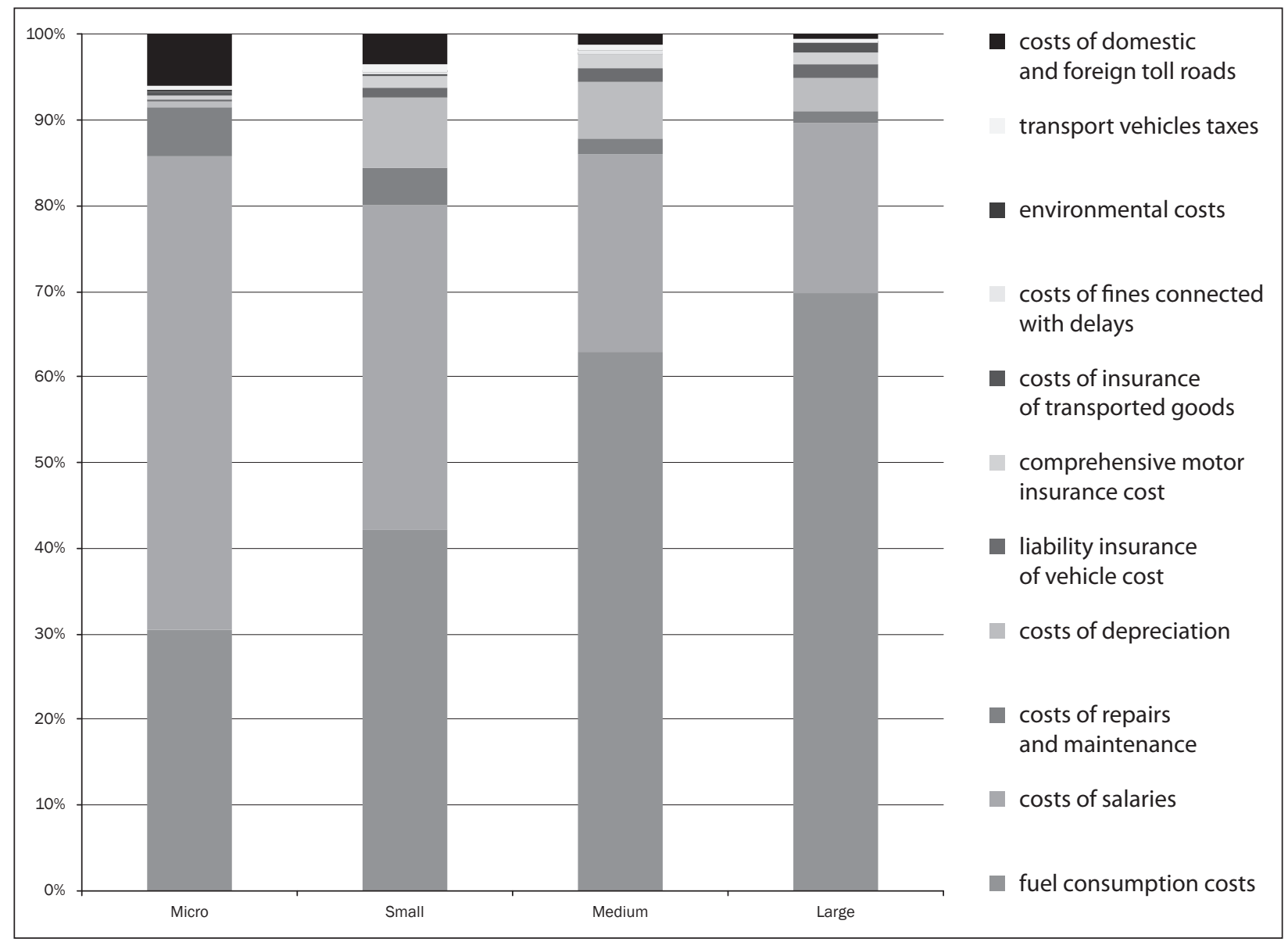

Figure 2 - Costs structure in road transport in studied entities according to company size in 2012 [percentage] Source: Author's elaboration

registration. Large companies bore the greatest costs for emitting gasses and dusts to the environment. Medium, small and then micro companies, which registered the greatest average costs of that kind in the year 2010, allocated significantly less for this purpose.

The level of transport means taxes grows along with the number of owned vehicles; therefore, medium and large companies have borne the most of it during the analysed period. In the years 2011 and 2012 medium and large companies bore the greatest costs on the account of the fees of transport means. In the whole period small companies bore half of that amount. In case of heavy-duty vehicles both at home and abroad, companies are obliged to use electronic system for the collection of payments.

Comparing the cost structure in enterprises of different operation scales, it should be noted that: the larger the company - the greater the share of fuel costs and the smaller the share of other costs dependent on the efficiency of the company management. The increase in scale of operations reduces the share of employment costs, repair costs, or the costs associated with penalties for delays in deliveries (Figure 2). On the other hand, the larger the company, the greater the desire to reduce the risk of business and so the costs related to the insurance of transport and insurance of transported goods account increase the share in the total costs. An important element of costs for micro companies are the fees for the use of domestic and foreign roads which in their case may be almost $6 \%$ of the total cost which in case of medium-sized enterprises constitute only $1 \%$ of the cost, and of large ones below $0.5 \%$.

To sum up the studies, the annual average number of orders in analysed companies fluctuated within the limits of 4.5 thousand. During their realization on the average about 6 million kilometres were covered and over a million of litres of fuel were consumed, with average annual cost ranging in the interval above 1.66 million euro annually. In the studied years the costs of repairs and maintenance of the owned vehicles amounted on the average to about 53.5 thousand euro annually; a considerable part of this was accounted by repairs of transport means of medium and large enterprises. The average costs of service in the examined companies amounted to about 0.8 thousand euro. Working hours of a single driver usually reached a maximum of 3 thousand hours, for which the average monthly salary fluctuated from 0.7 to 0.8 thousand euro gross monthly. The analysed entities paid on the 
average about 0.5 thousand euro annually on the account of payments for emitting gas and dust into the environment; however, annual costs borne by paying fees for using domestic and foreign roads amounted on the average to over 33.3 thousand euro.

The research result shows that cost structure in road transport enterprises is dependent on their size and performance volume. Analysing the cost structure in the surveyed enterprises, a huge impact of the cost of fuel can be noted, which accounted for $30 \%$ of all costs in the micro to $70 \%$ in the large companies. An important aspect is the significant level of employment cost in micro and small enterprises which account for $55 \%$ and $38 \%$, respectively, of the total cost, which is due to the relatively high fixed costs of employment distributed on the operations carried out on a smaller scale. It proves the thesis of the paper that this situation results in low efficiency and may in the long run contribute to serious problems with the functioning of this type of companies. The main paper findings are similar to those presented by Kulović [20] or McKinnon [25] where the high fixed costs of employment in smaller enterprises were noticed with great influence on performance efficiency; however, there is a limitation of the research results because of the Polish features (relatively smaller size) of road transport enterprises. So, there is strong need to continue studies using international sample that allows comparison.

\section{CONCLUSION}

Road transport is still most important in the present economic situation due to high logistic efficiency and flexibility in relation to other transportation modes. Better adaptation of road transport to logistics needs: the greatest density of road networks linking production, trade and consumption places, possibility of all cargo kinds transportation and better time duration considering door-to-door connections that render road transport the most useful at present and in the future.

Currently, freight transport market is increasingly feeling the effects of a slowing economy, which affects the condition of the collapse in the construction industry and the automotive crisis, particularly felt in the reduction of trade in goods with Spain, Greece and Italy and recently the collapse of exports to Russia and Ukraine. These problems do not translate into good financial situation of Polish transport companies and cause problems in fleet management as the forecast for the near future is not optimistic. In the near term action must be taken to optimise costs in order to reduce the negative effects of rising operating costs, decline in orders or reduction in the potential of businesses through lack of investments. Otherwise, it can be expected that a few thousand in particular micro and small transport companies will not be able to survive this difficult period.
Efficient road transport company management requires precise costs analyses and controls. As theory and research have shown, it is not simply a process because of cost identification problem due to insufficient accounting system used in transport companies; so many data required for the research questionnaires were calculated additionally because the accounting system cannot generate necessary costs juxtaposition.

The research results showed high difference in cost structures in road transport companies. The most significant is that the costs of large companies are rather dependent on fuel costs, which is rather irrespective of company management. It can be also confirmed that larger companies cut the costs inside the company better than small enterprises. Micro and small road transport companies require fast and effective costs control to avoid problems. Introduction of IT systems seems to be a good opportunity to control and cut the costs in those companies; however, it requires also necessary investments. So, the relations between necessary investments for IT introduction and the results in cost decrease and control are an interesting area for future studies.

Dr hab. inż. SEBASTIAN KOT, Prof. P.Cz.

E-mail: sebacat@zim.pcz.czest.pl

Politechnika Częstochowska

Wydział Zarządzania

Armii Krajowej 19B, 42-200 Czestochowa, Polska

\section{STRESZCZENIE}

\section{STRUKTURA KOSZTÓW W RELACJI DO WIELKOŚCI PRZEDSIĘBIORSTW TRANSPORTU DROGOWEGO}

Problem zarządzania kosztami w przedsiębiorstwach transportu drogowego jest jednym z najbardziej istotnych dla ich sprawnego funkcjonowania. Przedsiębiorstwa działające na rynku są bardzo różnorodne, a zatem ważne jest, aby analizować ich strukturę kosztów w relacji do ich wielkości. Autor prowadzi rozważania dotyczące identyfikacji kosztów w transporcie drogowym i problemów z tym związanych, w kontekście logistyki i zarządzania łańcuchem dostaw kosztów. Rozważania oparte są na bazie znaczenia transportu drogowego w usługach transportowych w Polsce i wybranych krajach Unii Europejskiej. Następnie, przedstawiono metodologię badań obejmującą opracowany kwestionariusz i zidentyfikowano próbę badawczą ze zwróceniem szczególnej uwagi na wielkość przedsiębiorstwa. Zaprezentowano szerokie badania dotyczące struktury kosztów w przedsiębiorstwach transportu drogowego w południowej Polsce, a także omówiono najważniejsze różnice w wielkości kosztów. Autor zauważył, różnice struktury kosztów w relacji do wielkości firmy, w szczególności dominację kosztów zatrudnienia w mikro i małych przedsiębiorstwach transportu drogowego oraz największy udział kosztów paliwa w większych firmach, co jest wynikiem lepszego zarządzania zasobami.

\section{SŁOWA KLUCZOWE}

transport drogowy; struktura kosztów; koszt paliwa; wielkość przedsiębiorstwa; analiza działania; 


\section{REFERENCES}

1] May GH. Transport in Europe: where are we going? Foresight. 2005;7(6):24-38.

[2] Banister D, Dreborg K, Hedberg L, Hunhammar S, Steen P, Akerman JA. Transport policy scenarios for the EU: 2020 images of the future. Innovation: The European Journal of So-cial Sciences. 2000;13(1):27-45.

[3] Guenther E, Greschner Farkavcová V. Decision making for transportation systems as a support for sustainable stewardship. Management Research Review. 2010;33(4):317-339.

[4] Forkenbrock DJ. Comparison of external costs of rail and truck freight transportation, Transportation Research Part A: Policy and Practice. 2001 May;35(4):321-337.

[5] Dima IC, Man M, Vlăduțescu Ş. The Company's Logistic Activity in the Conditions of Current Globalisation. Globalization, Education and Management Agendas; 2012. p. 263-294.

[6] Hensher D, Figliozzi MA. Behavioral insights into the modelling of freight transportation and distribution systems. Transportation Research Part B. 2007 Nov;41(9):921-923.

[7] Fleischmann B. Distribution and transport planning. In: Stadtler H, Kilger C, editors. Supply Chain Management and Advanced Planning: Concepts, Models, Software and Case Studies. Berlin: Springer; 2005. p. 229-243.

[8] Neider J. International transport [in Polish]. Warsaw: PWE; 2008

[9] EU Transport in Figures. Directorate-General for Energy and Transport European Commission; 2014.

[10] Information on the situation in road transport [in Polish]. Polish Ministry of Infrastructure; 2014.

[11] Łacny J. Benchmarking of costs in Polish international road transport enterprises [in Polish]. Logistyka. 2013;2:11-14.

[12] Romanow P. Transport costs in road transport enterprises performance [in Polish]. Logistyka. 2013;2:19 22.

[13] Ślusarczyk B. Transport importance in global trade. Advanced Logistic Systems. 2010;4:186-192.
[14] Grabara, J, Bajdor P, Okwiet B. Center as a Tool for Logistics Activities in Support of the Company on the Example of SME's Enterprise X. Polish Journal of Management Studies. 2010;2:35-43.

[15] Jakob A, Craig JL, Fisher G. Transport cost analysis: a case study of the total costs of private and public transport in Auckland. Environmental Science \& Policy. 2006;9(1):55-66.

[16] Ševrović M, Brčić D, Kos G. Transportation Costs and Subsidy Distribution Model for Urban and Suburban Public Passenger Transport. PROMET - Traffic \& Transportation. 2015;27(1):23-33.

[17] Kordnejad B. Intermodal Transport Cost Model and Intermodal Distribution in Urban Freight. Procedia-Social and Behavioral Sciences. 2014;125:358-372.

[18] Janic M. Modelling the full costs of an intermodal and road freight transport network. Transportation Research Part D: Transport and Environment. 2007;12(1):33-44.

[19] Hanssen TES, Mathisen TA, Jørgensen F. Generalized transport costs in intermodal freight transport. Procedia-Social and Behavioral Sciences. 2012;54:189-200.

[20] Kulović M. Freight Transport Costs Model Based on Truck Fleet Operational Parameters. PROMET - Traffic \& Transportation. 2004;16(6):321-325.

[21] Bentkowska-Senator K, Kordel Z, Waśkiewicz J. Small and medium-sized enterprises in road transport. Status - strategy [in Polish]. Warsaw: ITS; 2015.

[22] Tarkowski J, Irestahl B, Lumsden K. Transport - logistics [in Polish]. Poznań: Biblioteka Logistyka; 2005.

[23] Brzeziński S, Ślusarczyk B, Biazik M. Cost Analysis of Using Transport Infrastructure in Chosen Countries of the European Union. In: Lorca P, Popescu C, editors. Recent Researches in Applied Economics and Management. Economic Aspects of Environment, Development, Tourism and Cultural Heritage. Vol. 2. WSEAS Press; 2013.

[24] Hillman KM, Sanden BA. Exploring technology paths: the development of alternative transport fuels in Sweden 2007-2020. Technological Forecasting and Social Change, 2008;75:279-302.

[25] McKinnon A, Ge Y, Leuchars D. Analysis of transport efficiency in the UK food supply chain. Edinburgh: Logistics Research Centre, Heriot-Watt University; 2003. 